\title{
O DISCURSO PUBLICITÁRIO E A CRIAÇÃo DE PALAVRAS NOVAS: O DESENVOLVIMENTO DA COMPETÊNCIA LEXICAL
}

\author{
Aderlande Pereira Ferraz*
}

\begin{abstract}
RESUMO: Este artigo, numa perspectiva pedagógica, trata do desenvolvimento da competência lexical a partir da análise de textos publicitários e mostra a renovação do léxico do português brasileiro pelos processos mais comuns de neologia. O objetivo é ressaltar a importância do discurso publicitário no âmbito escolar, explorando, sobretudo, os aspectos de criatividade discursiva e de inovação semântico-lexical. No âmbito da competência lexical, o artigo discute o que significa conhecer uma palavra e, para a conceituação de neologismo, adota o critério lexicográfico (ALVES, 1984, 1990; SANDMANN, 1989; CABRÉ, 1993), em que a unidade lexical será neológica se ainda não estiver registrada em um dicionário de língua. Nesse contexto, o que se pretende é enfatizar o trabalho com textos publicitários na sala de aula de língua portuguesa, com base em um estudo descritivo de alguns neologismos midiáticos, obtidos de anúncios publicitários que evidenciam a criatividade no português brasileiro, por meio do aparecimento de palavras novas.
\end{abstract}

PALAVRAS-CHAVE: Competência lexical; discurso publicitário; Neologismo.

\section{Considerações iniciais}

Entre os objetivos do ensino de língua materna, encontra-se no centro o desenvolvimento da competência linguística, a partir do qual se busca formar usuários competentes da língua que sejam capazes de, em variadas situações de interação comunicativa, produzir adequadamente textos orais ou escritos e de compreender os textos orais ou escritos que recebem. Não se pode negar, com isso, a importância dos elementos de natureza formal,

\footnotetext{
* Professor associado da Universidade Federal de Minas Gerais (UFMG), onde também atua como docente permanente do Programa de Pós-graduação em Estudos Linguísticos. Doutor em Linguística e Língua Portuguesa pela Universidade Estadual Paulista Júlio de Mesquita Filho (Unesp). Realizou estágio de pós-doutorado na Universidade de São Paulo (Usp).
} 
relacionados com os diversos componentes da língua, e essenciais para a estruturação de textos.

Nesse âmbito, importa destacar os elementos que dizem respeito ao léxico, ainda tão marginalizados no ensino de língua portuguesa (CRUZ, 2015; CUNHA, 2012), o que põe o ensino do léxico, na educação básica, como uma lacuna que não foi ainda devidamente preenchida.

Como toda língua em evolução apresenta variações e mudanças em todos os seus constituintes, a obsolescência de unidades lexicais que caem em desuso e o surgimento de novas unidades na língua, os neologismos, são ocorrências naturais, previstas nos padrões de estruturação lexical das línguas vivas, como salienta Ferraz (2008). Assim, quando se percebe no léxico uma nova forma, uma nova acepção associada a uma forma já existente ou um estrangeirismo importado de outro sistema linguístico, tem-se, para cada caso, um neologismo figurando como uma palavra nova.

Com tais considerações, desejamos pôr em evidência o ensino do léxico e apresentamos a seguir a análise de alguns neologismos presentes em textos do gênero publicitário, coletados da mídia eletrônica, num esforço de contribuir para que trabalhos de investigação acadêmica alcancem um público maior, especialmente os agentes diretamente ligados à educação básica.

Neste trabalho, que leva em consideração estudantes do ensino médio, destaca-se o valor de se trabalhar com materiais didáticos autênticos, em particular os textos do gênero publicitário. O objetivo é ressaltar a importância do gênero publicitário no âmbito escolar, explorando, sobretudo, os aspectos de criatividade discursiva e de inovação semânticolexical. Nesse contexto, o que se pretende é mostrar que a didatização de textos publicitários na sala de aula de língua portuguesa é possível, com base em um estudo descritivo de alguns neologismos midiáticos, obtidos de anúncios publicitários, evidenciando, com isso, a criatividade no português brasileiro, por meio do aparecimento de palavras novas.

Desse modo, apresentamos alguns aspectos da inovação lexical no português do Brasil, com vários tipos de neologismos, numa caracterização da competência lexical, a 
partir da qual se tenta conhecer como o usuário da língua entende as palavras, sua estrutura ou constituição e seus relacionamentos com outros elementos lexicais.

\section{O gênero publicitário e a inovação lexical}

O discurso publicitário, caracterizado por um conjunto de técnicas a influir no comportamento das pessoas, induzindo-as a consumir determinados produtos ou a realizar determinados serviços, é um discurso sempre persuasivo, eivado, todo ele, de vários recursos estilísticos. Atualmente, é inegável a forte influência social que o discurso publicitário exerce, em meio à comunidade linguística onde atua, revelando-se, pelos diversos modos com os quais se manifesta, bem como pelo grande alcance a que se projeta, um dos principais poderes sobre a opinião pública (GONÇALVES, 2006).

Para criar interação e agir sobre o outro, o virtual consumidor, o discurso publicitário se apoia claramente no dialogismo, princípio fundamental para garantir a adesão do receptor. Como resultantes dessa interação, surgem as relações entre linguagem e mídia, a partir das quais é possível ver uma grande manifestação de criação lexical na mídia publicitária brasileira, ensejando a renovação do léxico do português contemporâneo.

Com o objetivo de persuadir o receptor a aderir a certas ideias, o discurso publicitário se erige fortemente marcado por duas características: (i) o apelo para o desejo e a fantasia das pessoas, utilizando-se de imagens e vários recursos da língua, como nomes de produtos motivados, grafias exóticas, aspectos fonéticos (rima, ritmo, aliteração), aspectos lexicais (formações neológicas de variada tipologia), aspectos semânticos (jogo com as palavras, alternando os sentidos denotativo e conotativo) etc.; (ii) um vocabulário especial que abarca, além de unidades lexicais da língua comum, uma diversidade de termos ligados a vários domínios, constituindo unidades terminológicas de várias áreas de especialidade.

O uso dos recursos da língua é essencial para a publicidade atingir seus objetivos. Com isso, a linguagem da publicidade constitui um amplo campo para investigação, sob vários aspectos, e especialmente do ponto de vista lexical. É que a linguagem publicitária, fortemente caracterizada pela dinamicidade do léxico, sente-se permanentemente impulsionada a renovar-se, não apenas para nomear 
mercadorias, mas sobretudo por tecer enunciados cheios de apelos estilísticos que procuram divertir, motivar, seduzir, fazer sonhar, excitar ou entusiasmar, tornando, assim, a produção de neologismos um fator inevitável. Em face disso, a linguagem da publicidade tem sido uma força extraordinária a incidir sobre a língua portuguesa, no sentido de forçar uma contínua transformação linguística, com reflexos em vários aspectos da língua e, com especial destaque, no campo lexical, com a criação de palavras novas. (FERRAZ, 2010, p. 258)

Em face disso, as unidades lexicais, no discurso publicitário, são escolhidas mediante sua possibilidade de evocar determinados valores ou certas representações. E quando estas unidades lexicais não se encontram disponíveis (prontas) no sistema da língua, surge a necessidade de criá-las, seja para nomear produtos ou serviços inéditos ou para evocar na memória do receptor produtos ou serviços já existentes, como se estes fossem inéditos.

Um exemplo disso é o anúncio publicitário da figura 1, em que sobressai o jogo com as palavras pela alusão que faz à operação policial que se tornou famosa no Brasil por deter e prender diversos políticos e empresários brasileiros. Em tal anúncio, é formada uma expressão nova cujo sentido é construído não apenas em referência à nova embalagem do preservativo masculino, mas principalmente pela função do produto: “operação guardajato".

Figura 1 - Anúncio publicitário

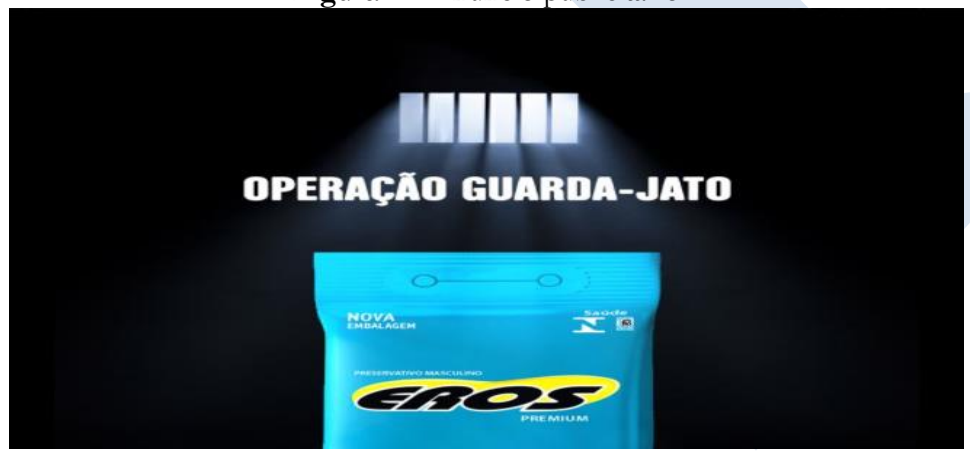

Disponível em: <http://www.juruemdestaque.com/2017/05/

preservativo-masculino-eros-premium-faz.html> Acesso em 20/08/2018. 
A observação sistemática de textos publicitários permite-nos identificar o fenômeno da neologia na língua portuguesa, e, decorrente disso, observar a competência lexical do usuário da língua, ou seja, como este entende as palavras, sua estrutura ou constituição, e seu relacionamento semântico-formal com outros itens lexicais que integram o léxico geral.

\section{O conceito de neologismo}

A inovação lexical, por meio da neologia, nos faz refletir sobre a necessidade de se adotar um critério para delimitar a palavra nova. Para muitos estudiosos do léxico (ALVES, 1984, p. 121 e 1990, p. 10; SANDMANN, 1989, p. 8; CABRÉ, 1993 etc.), a noção de neologismo está atrelada ao dicionário de língua. Entretanto, algumas questões se levantam vez por outra, entre vários estudiosos, procurando saber quais elementos identificam o neologismo, ou como comprovar e demonstrar o sentimento de novidade perante uma unidade léxica considerada nova ou, em outras palavras, quais as condições que um item léxico teria de cumprir para ser considerado um neologismo.

Vários critérios podem ser aventados para a identificação do neologismo, como se pode inferir pelas considerações de Guilbert (1975: 34) e Boulanger (1979), as quais se encontram sintetizadas em Cabré (1993, p. 445): "critério diacrônico" (é neológica a unidade lexical que surgiu em um período recente); "critério lexicográfico" (a unidade lexical será neológica se ainda não estiver registrada em um dicionário de língua); “critério de instabilidade sistemática" (a unidade será neológica se apresentar, em suas ocorrências, traços de instabilidade formal [fonética, morfológica ou gráfica] e semântica; "critério psicológico" (uma unidade lexical é neológica se os usuários da língua a percebem com sensação de novidade).

Como princípio metodológico, adotou-se, neste trabalho, o critério lexicográfico, por seu caráter objetivo e prático. É sabido que tal critério se ressente de maior precisão pelo fato de os dicionários não se atualizarem com mais frequência. Além disso, um dicio- 
nário jamais poderá conter todas as palavras de uma língua. Contudo, o critério lexicográfico tem sido, pela facilidade de aplicação como também pela objetividade na obtenção dos dados, o mais usual entre aqueles que trabalham com neologismos.

Desse modo, os exemplos de neologismos que se seguem, recolhidos de textos publicitários, veiculados por sítios da internet e pelas revistas noticiosas Veja e Época, foram assim identificados pelo o critério de exclusão lexicográfica, a partir da filtragem por meio de um repertório lexicográfico ou, na expressão de Boulanger (1979), de um "corpus de exclusão”, o qual congrega vários dicionários de língua nos quais o candidato a neologismo não deve estar registrado. Então, como “corpus de exclusão”, foi considerado o conjunto de quatro dicionários escolares direcionados ao ensino médio, avaliados pelo Programa Nacional do Livro Didático (PNLD-Dicionários) e distribuídos às escolas públicas brasileiras em 2012. Tais dicionários examinados encontram-se relacionados na seção de referências, que encerra este artigo.

Em consideração ao exposto, reconhecemos o neologismo formal, em que a unidade léxica foi criada a partir dos padrões de formação e estruturação lexicais disponíveis na língua, tal como apresentado no anúncio em (1), no qual a unidade neológica "leitorassinante" é o leitor que também é assinante da revista.

(1) "No clube, o leitor-assinante Abril tem acesso a tudo o que mais gosta" (Veja, 14/01/2015, p. 28) disponível em < http://abril.assineabril.com.br/hotsite/digitais/revistas_digitais.html\#baixar_revista>, acesso em 20/08/2018).

Também reconhecemos o neologismo semântico, em que a forma lexical já dicionarizada apresenta-se com uma significação diferente da atestada, como se observa no anúncio em (2), no qual "fixo", a unidade neológica, aparece significando o tipo de telefonia oferecido por uma operadora de serviços telefônicos.

(2) "Conheça os planos Ilimitados para fixos e celulares Vivo. Fale com todo o Brasil e economize muito mais com os planos Vivo Fixo. (Disponível em https://assine.vivo.com.br/telefonia?_ga= 2.179578660.148313925.1535457717-524355196.1535457717>; acesso em 20/08/2018). 
No mesmo contexto, identificamos o neologismo por empréstimo, em que um estrangeirismo lexical é adotado pela língua receptora, como é o caso de "food truck", no anúncio em (3).

(3) "Food truck: hora de investir em um novo modelo de negócio. Fique por dentro de tudo sobre a regulamentação e o modelo de negócio dos food trucks." Sebrae Nacional. (Disponível em <http://www.sebrae.com.br/sites/PortalSebrae/artigos/food-tru ck-uma-nova-tendencia,d128e6f7c633c410VgnVCM2000003c7401 0aRCRD >; acesso em 09/03/2018).

Significando comércio de comida de rua em veículos sobre rodas, sem a necessidade de adquirir ponto comercial ou outros encargos, tem-se aqui a unidade "food truck" como um estrangeirismo do inglês, em pleno uso no português do Brasil, sem estar ainda dicionarizada.

\section{O desenvolvimento da competência lexical}

Considerando a competência lexical como a capacidade de compreender as palavras, na sua estrutura morfossintática e nas suas relações de sentido com outros itens lexicais constitutivos da língua, reconhecemos que é papel da escola contribuir para o seu desenvolvimento, o qual, por consequência, leva ao desenvolvimento da competência comunicativa. É nesse contexto que muitos professores se perguntam que extensão do léxico se deve saber para maior destreza no desempenho comunicativo, oral e escrito.

Entretanto, conhecer mais amplamente o léxico de sua língua é de suma importância para todo falante; conhecimento que não deve ser apenas quantitativo, mas fundamentalmente qualitativo.

Richards (1985, p. 176-188), em importante estudo sobre o que significa conhecer uma palavra, destaca diversos aspectos básicos, os quais envolvem o conhecimento de suas propriedades, do grau de probabilidade de encontrar essa palavra em sua forma falada ou escrita, e de sua forma subjacente. 
Embora esteja voltado para o ensino de língua estrangeira, o estudo de Richards pode ter aplicação também ao ensino de língua materna, especialmente quando se considera a palavra nova, o neologismo. Assim, o autor aponta, entre outros, os seguintes fatores que concorrem para o amplo conhecimento de uma palavra.

a) O usuário da língua, além de reconhecer as probabilidades de ocorrência de uma unidade léxica, reconhece também a probabilidade de umas unidades estarem associadas a outras.

b) Ao conhecer uma unidade léxica, o falante reconhece as características desta que se relacionam com as variações de tempo, lugar, papéis sociais e campos semânticos. O conhecimento de uma unidade léxica pressupõe saber quais as suas limitações de uso impostas.

c) Em nosso léxico mental, as unidades léxicas não estão armazenadas simplesmente como conceitos, estão associadas a estruturas específicas e a propriedades gramaticais. Por isso, o conhecimento de um item lexical implica saber qual é o seu comportamento sintático.

d) Ao conhecer uma unidade léxica, o falante aprende também os padrões gerais de estruturação que lhe permitem construir outras formas, derivadas ou compostas. Assim, o conhecimento de uma palavra estende-se ao conhecimento de sua forma subjacente e de suas possibilidades de derivação ou composição.

e) Os significados das unidades léxicas são definidos a partir de suas relações com outros itens lexicais nos atos discursivos. A compreensão dessas relações conduz à compreensão das unidades léxicas. Portanto, ao conhecer uma palavra, o falante deve revelar o conhecimento da rede de associações entre essa e outras palavras da língua.

f) O significado de uma unidade léxica pode ser visto em termos de um amplo conceito, muito mais rico do que parece, a refletir-se como a base sobre a qual um conjunto de sentidos agregam-se. Por isso, conhecer uma palavra implica conhecer muitos dos diferentes sentidos a ela associados. 
Em face de tais aspectos, é possível perceber a necessidade do estudo do léxico em sala de aula de língua portuguesa como a razão fundamental para se alcançar o principal objetivo do ensino de português: formar usuários competentes da língua que sejam capazes de, em variadas situações de interação comunicativa, produzir adequadamente textos orais ou escritos e de compreender os textos orais ou escritos que recebem.

\section{Neologismos formais no discurso publicitário}

A união de duas ou mais bases para formar uma nova palavra com um sentido único e constante é o que se denomina composição. A unidade composta forma um todo, semanticamente. Em geral, ela tem uma significação global que pode ser independente da soma das significações das partes componentes ou partir do valor semântico de uma das partes. Em nosso corpus, os neologismos formados por composição apresentam caráter subordinativo e coordenativo. A seguir, estão alguns exemplos de formações compostas por subordinação (salário-maternidade, auxílio-doença, fotolivro, audiodescrição, audioguia), em que se percebe a relação de determinado (o núcleo) e determinante (o periférico), como em (4) e na figura 2.

(4) Neologismos compostos por subordinação:

É muito bom saber que temos uma Previdência Social que há quase um século nos ampara com o salário-maternidade, auxílio-doença, pensão e aposentadoria, entre outros benefícios. (Veja, 18/01/2018, p. 69, disponível em <http://abril.assinea bril.com. br/hotsite/digitais/revistas_digitais.html\#baixar_revista $>$, acesso em 20/08/2018.)

Na compra de uma câmera Canon, você ganha um fotolivro personalizado. Canon - o melhor click. (Veja, 06/05/2015, p. 27, disponível em <http://abril.assineabril.com.br/hotsite/digitais/revistas_digitais.html\#baixar_revista>, acesso em 20/08/2018.) 
Figura 2 - Anúncio publicitário

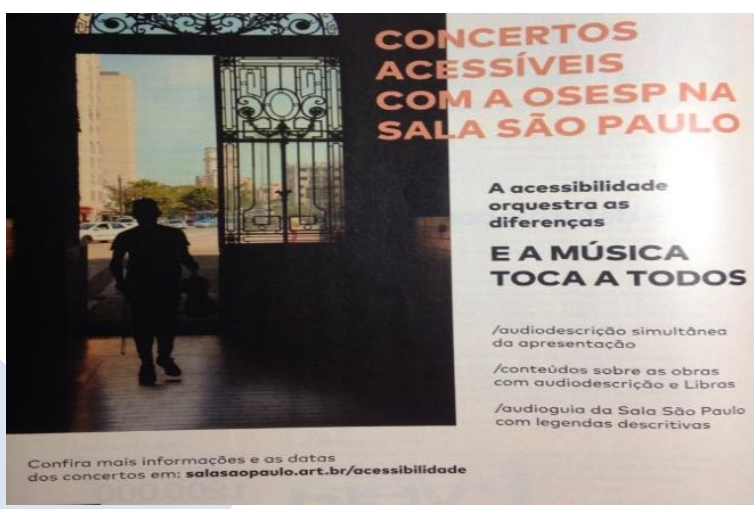

Disponível em < http://abril.assineabril.com.br/hotsite/digitais/revistas_di gitais.html\#baixar_revista>,Veja, 06/09/2017, p. 69). Acesso em 20/08/2018.

Em (5) estão alguns neologismos compostos por coordenação (sócio presidente, fixo-móvel, artístico-cultural), em que cada elemento é independente e o valor semântico global é a soma dos valores parciais, ou seja, "sócio-presidente” é um sócio que se tornou presidente da empresa.

(5) Neologismos compostos por coordenação:

Já pensou ter uma agência onde o Sócio-Presidente é o Celso Loducca? Empresário sócio da Casa do Saber, da Cereja/PRN, 25 anos de carreira. Em 1995 fundou a Loducca, uma das 3 agências mais admiradas pelos próprios profissionais do mercado. Loducca. MPM. (Veja, 09/12/2010, p. 146, disponível em <http://abril.assineabril.com.br/hotsite/digitais/revistas_digitais.html\#baixar_revista>, acesso em 20/08/2018.)

Chamadas fixo-móvel não fazem parte do plano e serão tarifadas pelo Plano Básico. Oi. (Época, 06/08/2009, p. 54)

(...) Tudo para a preservação do patrimônio artístico-cultural. (Época, 22/08/2008, p. 78) 
Em Guilbert (1975, p. 101-102), encontra-se a denominação neologia sintagmática usada para fazer referência aos sintagmas terminológicos dos vocabulários científicos e técnicos. O neologismo sintagmático surge como resultado do processo de lexicalização. Isto é, uma formação sintagmática está se lexicalizando quando começa a perder as características que a situavam como segmento da frase, a exemplo de quando deixa de ser uma combinação livre para assumir uma estrutura morfossintática fixa. Com isso, pode-se considerar que o processo de lexicalização se instaura quando uma sequência léxica, formada por mais de um elemento lexical, chega a funcionar, nos discursos oral ou escrito, como uma só unidade lexical.

Nesse contexto, o composto sintagmático pode se apresentar como um neologismo da língua comum (bagagem de mão, leitores de banca, qualidade de vida), como mostram os anúncios em (6), ou como um neologismo terminológico (Sistema de tração 4WD; controle ativo de estabilidade, comandos de áudio, piloto automático, teto panorâmico Sky view, sistema multimídia, Sensores de luz, freio a disco, Sistema Full Air Bags, assistente de partida em rampa, serviço de bordo, taxa zero) como os que se apresentam no anúncios em (7).

(6) Neologismos sintagmáticos com elementos do léxico comum:

Com o e-TAM Auto Atendimento, passageiro com e-ticket, com bagagem de mão, emite o cartão de embarque em segundos, sem complicação. (Época, 09/02/2008, p. 04)

Um presente da Azul Music exclusivo para leitores de banca, com a sua revista Caras. (Época, 02/01/2008, p. 93)

O Mosaico de Unidades de Conservação do Lago preserva a biodiversidade e melhora a qualidade de vida da população local. (Época, $22 / 11 / 2008$, p. 08)

(7) Neologismos sintagmáticos com elementos comuns e de especialidade:

Off-road - Sistema de tração 4WD; controle ativo de estabilidade (ASC). Conforto - Bancos de couro com aquecimento nos dianteiros e ajuste elétrico para o motorista; comandos de áudio e piloto automático no volante; teto panorâmico Sky view. Tecnologia - sistema multimídia com GPS em português, DVD, MP3, Bluetooth; 
Sensores de luz, chuva e estacionamento. Segurança - Freio a disco nas 4 rodas com ABS, EBD e BAS; Sistema Full Air Bags: frontais, laterais, de cortina e para o joelho do motorista; assistente de partida em rampa (HSA). (Veja, 05/08/2015, p. 20, 21)

Serviço de bordo impecável. É assim que você vai voar. Azul. (Veja, $04 / 11 / 2015$, p. 25)

Toda a linha 60 T5 com entrada de $50 \%+18$ parcelas e TAXA ZERO. Volvo. (Veja, 17/02/2016, p. 21)

Ainda em consideração à neologia formal, importa considerar os casos de derivação afixal. Em português, como nas línguas românicas em geral, a derivação tem sido um processo muito produtivo para o enriquecimento do léxico, apresentando como mais frequentes os casos de prefixação e de sufixação. $\mathrm{Na}$ derivação prefixal tem-se um prefixo e uma base, cabendo ao primeiro expressar uma ideia comum e geral e à base uma ideia particular ou menos geral. Em (8), as formações prefixais (procaminhoneiro e superfeirão) apresentam caráter substantival.

(8) Neologismos formados por derivação prefixal:

Taxas a partir de 0,37\%. Programa Procaminhoneiro. Iveco TECTOR (Caminhão). (Veja, 28/07/2010, p. 112)

Preços incríveis? Só no superfeirão Gol. Aproveite. Gol Linhas Aéreas. (Veja, 28/07/2010, p. 126)

A produtividade do neologismo prefixal em português é, majoritariamente, nominal. Entretanto, encontramos uma ocorrência cuja formação é de caráter verbal ("multitelar"), como se apresenta em (9).

(9) Neologismo prefixal de caráter verbal:

Tem acesso gratuito ao NOW. Para você assistir, em alta definição, milhares de conteúdos dos canais do seu pacote de TV e multitelar não só na TV, mas no seu computador, tablet ou smartphone. Você assiste onde e quando quiser! (Disponível em <https://www.net. com.br/> Acesso em 20/07/2018.) 
Na derivação sufixal é possível perceber que entre a base original e o sufixo desenvolve-se uma interação dinâmica, envolvendo os aspectos formal, semântico e funcional, o que favorece o surgimento de uma nova palavra vinculada à original. É o que se pode ver pelos exemplos (frotistas, poupançudos, promessômetro) em (10).

(10) Neologismos formados por derivação sufixal:

A linha de caminhões TGX, testada e aprovada pelos frotistas. MAN. (Veja, 29/04/2015, p. 26, 27)

Chegou a seleção dos poupançudos. Abra uma poupança na Caixa, faça um depósito a partir de 100 Reais e ganhe o seu. CAIXA ECONÔMICA FEDERAL. (Veja, 16/06/2010, p. 06)

Pelo site: Ambiente especial, com todas as informações sobre a campanha e ferramentas especiais: PROMESSÔMETRO, onde o leitor poderá avaliar as promessas de campanha de cada candidato. O GLOBO. (Veja, 25/08/2010, p. 120)

Outro neologismo formal presente na linguagem da publicidade é aquele que resulta da aglutinação (ou amálgama) de duas bases, quando estas perdem parte de seus elementos para formarem uma nova unidade do léxico, por meio da mesclagem de palavras já existentes. O neologismo “sextaneja”, presente no anúncio publicitário da figura 3, foi criado pelo processo de cruzamento lexical, também conhecido como palavra-valise, contaminação, amalgama, blending etc.

Figura 3 - Anúncio publicitário

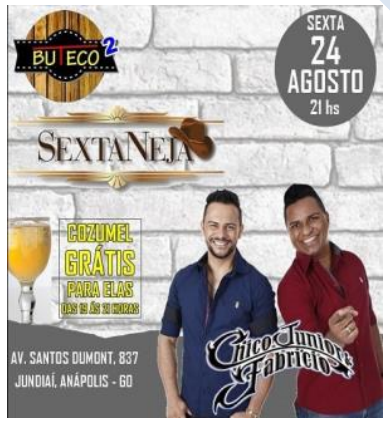

Disponível em < http:/ /gramha.com/explore-hashtag/sextar>Acesso em 21/08/2018. 
Trata-se do cruzamento de sexta-feira com sertaneja, significando 'o dia da semana reservado para apresentações musicais do gênero sertanejo’.

Sobre o processo de construção do cruzamento lexical, importa considerar as palavras de Sandmann.

Onde se faz o corte é naturalmente opção de quem cria a palavra, ressalvando-se que deve ser respeitada a estrutura silábica da língua. Como essas formações não obedecem a modelos estabelecidos na língua, caso da derivação e da composição, Marchand (356) dá ao cruzamento vocabular o nome de "word-manufacturing", manufatura de palavras. A denominação me parece muito apropriada, porque não temos uma produção em série ou de linha de montagem, caso principalmente de processos de sufixação (breguice, fajutice, pentelbice) e de prefixação (superpasta, super-roubo, superestádio, superdimensionamento), mas a produção de forma por forma, como que artesanalmente. (SANDMANN, 1992, p. 58)

Esse aspecto artesanal de que fala Sandmann se aplica bem às formações lexicais encontradas em textos publicitários. É nesse contexto que certas campanhas publicitárias provocam o público a que se destinam, produzindo formas e sentidos inusitados, utilizando-se muitas vezes de grafias exóticas, mas sempre explorando as possibilidades que os padrões da língua oferecem. $\mathrm{Na}$ figura 4, vê-se o cruzamento lexical que ocorre pela fusão da unidade léxica digital com o nome do banco, responsável pelo anúncio, formando o neologismo "digitau".

Figura 4 - Anúncio publicitário
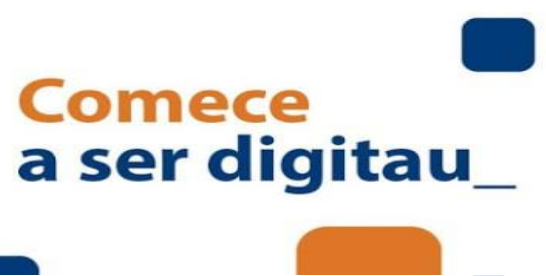

<https://www.apkparapc.com/Ita\%C3\%BA-Light-para-PC-gratis,1950796/> Acesso em 30/11/2018. 
O anúncio da figura 4 se insere na campanha publicitária criada com o objetivo de estimular o uso de um aplicativo para a realização de operações bancárias. Tal campanha foi criada para as redes sociais e outras mídias online numa sequência de vários filmes. $\mathrm{O}$ anúncio, no entanto, ficou centrado na formação neológica "digitau", que, em realidade, é um neologismo estilístico, criado para produzir efeitos expressivos que despertem a atenção do público a que se destina para o objetivo da campanha publicitária.

\section{Neologismos semânticos no discurso publicitário}

O signo linguístico, tal como definido por Saussure (1916), é formado pela associação indissolúvel de uma forma, o significante, e um conteúdo, o significado. Embora se possa, para efeito de análise, examinar cada componente isoladamente, os dois estão intrinsecamente unidos e, na língua, cada qual existe em função do outro. No entanto, se a união de tais componentes é um fato observável, por outro lado, essa associação não é logicamente motivada, o que evidencia a arbitrariedade do signo linguístico. Este, além de se caracterizar por seu significante e seu significado, se caracteriza ainda, no uso linguístico, pelas propriedades que lhe permitem engendrar combinatórias, na relação com outros signos.

Nesse contexto, podemos considerar as unidades do léxico como signos linguísticos. Isto é, cada unidade do léxico de uma língua se constitui de significante e significado, podendo estabelecer relações combinatórias com outras unidades lexicais. Com isso, entretanto, importa considerar que uma forma (significante), componente de um signo linguístico dado, pode se unir a outro significado, formando então um signo linguístico diferente. Esta mesma operação, no âmbito lexical, ocorre quando, de uma unidade do léxico, a forma (significante) se associa a outro significado, o que dá origem a outra unidade lexical. E daí se depreende que usos de uma mesma forma lexical podem ser semanticamente diferentes ou iguais, semanticamente relacionados ou não. Nesse processo, podemos ver o surgimento do neologismo semântico. Ou seja, um novo significado pode ser atribuído a 
uma base formal já existente, transformando-a em neologismo semântico, com possibilidade de atuar em outro contexto de uso. Em decorrência da reutilização de formas lexicais com significados novos, os neologismos semânticos surgem então da transformação semântica, sem qualquer alteração formal.

Em “audiência monstro", no anúncio da figura 5, tem-se um novo significado para a forma "monstro", ainda não atestado nos dicionários.

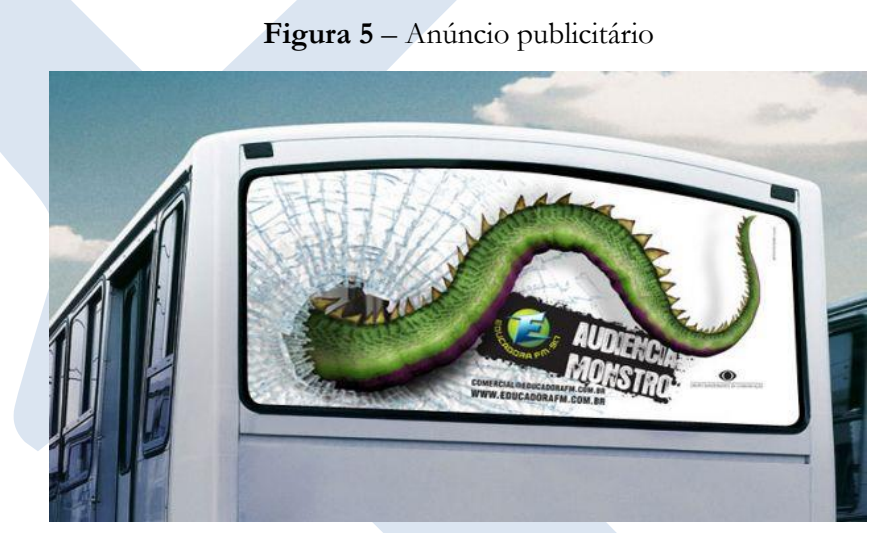

Disponível em $<$ https://www.iped.com.br/materias/enem-gratis /pecas-publicitarias.html> Acesso em 19/07/2018.

Com isso, "monstro" surge como um neologismo semântico, usado no anúncio publicitário da estação radiodifusora para dar ideia da grande audiência alcançada.

$\mathrm{Na}$ figura 6, o anúncio publicitário traz a unidade léxica "maquininhas", significando 'maquinas utilizadas para registrar compras por meio do cartão de crédito ou cartão de débito’. 
Figura 6 - Anúncio publicitário

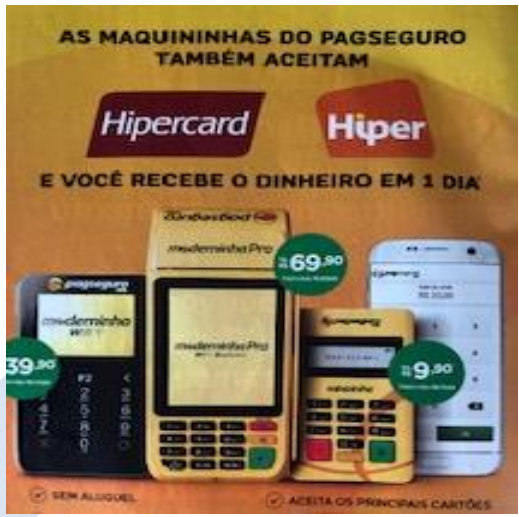

<http://abril.assineabril.com.br/hotsite/digitais/revistas_digitais.html \#baixar_revista>,Veja, 06/09/2017, p. 19). Acesso em 20/08/2018.

No repertório lexicográfico de que se compõe o corpus de exclusão usado aqui como filtro para a identificação de neologismos, não há o registro da forma lexical "maquinha”. Ocorre que os dicionários não registram, de modo geral, as formas em diminutivo, cuja extensão de sentido é apenas gramatical, e, por isso mesmo, facilmente previsível para os consulentes. Registram tais formas, contudo, quando elas carreiam outros significados lexicais, como é o caso, por exemplo, de coxinha (bolinho em forma de coxa de galinha) ou de covinha (pequena dobra na pele do queixo ou das bochechas). Nesse sentido, esse é o caso também do neologismo semântico "maquinha”, ainda não dicionarizado. Provavelmente, numa próxima edição, os dicionários escolares aqui utilizados venham incluir, como nova entrada, a forma lexical "maquinha" com o significado expresso no anúncio publicitário da figura 6.

\section{Considerações finais}

Como observa Gonçalves (2016, p. 11), a criação de palavras novas, seja por qualquer processo, é um ato tão rotineiro que muitas vezes os usuários da língua não se dão conta da sensação de novidade que tais palavras despertam. 
Para cunhar novas experiências, no entanto, não nos valemos apenas da importação de palavras, como pode parecer à primeira vista. Também somos bastante criativos. Podem ser considerados relativamente recentes ofícios como chapeiro ('aquele que trabalha na chapa, fazendo, por exemplo, hambúrgueres') e cachorreiro ('aquele que passeia com cachorros), ambos criados a partir da adjunção do sufixo -eiro a formas vernaculares (nativas). Também é recente a contratação de pessoas para tomar conta de idosos, população cada vez maior nas sociedades modernas. A forma cuidador, totalmente vernácula, foi utilizada para nomear esse tipo de profissional. (GONÇALVES 2016, p. 13)

De modo geral, os neologismos surgem por necessidade de comunicar algo novo ligado às experiências humanas ou pela busca de expressividade, quando se deseja introduzir à comunicação algum elemento estético novo. Ao tratar do neologismo necessário em face do neologismo expressivo, Guilbert (1975, p. 40-41) os distinguiu como "neologismo denominativo" e "neologismo estilístico", respectivamente. O primeiro diz respeito à necessidade de exprimir conceitos ou nomear realidades novas (produtos, serviços, objetos, ideias); o outro é uma criação neológica estilística, motivada pela busca de maior expressividade do discurso. Os neologismos denominativos apresentam grande chance de fixação no sistema linguístico, ao passo que os neologismos estilísticos, existindo, por vezes, só ao nível do discurso, como costuma acontecer na mídia publicitária, não passam de formações efêmeras, entrando muito raramente no sistema da língua, por ficarem fora do uso geral e corrente. Não obstante, os textos literários trazem, não raro, neologismos estilísticos que marcam ou consagram seus autores, pelo efeito especial que produzem e por fugirem do uso comum da língua, sem prejuízo da comunicação. Nas obras de Sousândrade, Guimarães Rosa, Carlos Drummond de Andrade, João Antônio, entre tantos outros, os neologismos estilísticos são caracterizadores do estilo individual, na medida em que, de maneira inédita, tais autores usam da criação lexical para trabalhar esteticamente a sua criação literária.

As formações neológicas encontradas em textos publicitários apresentam-se, basicamente, sob esses dois aspectos, com forte predominância dos neologismos denominativos, como demonstraram os exemplos no corpo deste artigo. O neologismo estilístico, 
também muito comum no discurso humorístico, em manchetes jornalísticas e no noticiário político, aparece no discurso publicitário como nos seguintes exemplos, em que a base inicial é a redução do nome da marca do produto (Motorola):

Motonatal com superdescontos: $10 \mathrm{x}$ sem juros e aparelho grátis. (Veja, 18/12/2002, encarte)

Motopromoção na Oi. - (Veja, 18/12/2002, encarte)

As duas formações neológicas "motonatal" e "motopromoção" surgiram por uma motivação circunstancial, uma vez que a campanha publicitária se deu por ocasião do Natal, e, partindo de um nome próprio, tais formações se caracterizam pela busca de efeitos expressivos, mas com pouquíssima chance de ganhar uso corrente no português brasileiro, o que se pode deduzir pela ausência de registro, até hoje, nos principais dicionários brasileiros e pela falta de novas ocorrências em campanhas publicitárias subsequentes. Na mesma linha de ocorrência, está o caso anteriormente mostrado de "digitau".

Esses três neologismos estilísticos têm, certamente, vida efêmera, subsistindo apenas durante a vigência da campanha publicitária. Entretanto, neologismos dessa categoria costumam ter uma passagem quase sempre marcante na comunidade linguística e revelam as muitas possibilidades de inovação lexical no português do Brasil.

Em realidade, tais apontamentos sobre o neologismo são de grande importância para quem deseja trabalhar com os aspectos lexicais em sala de aula, ensejando a visão mais ampla sobre o que se passa no português brasileiro, com respeito aos casos mais frequentes e produtivos de formação de palavras novas.

Enfim, procuramos, com este trabalho, ressaltar a importância do desenvolvimento da competência lexical no âmbito escolar, a partir de textos do gênero publicitário. A análise dos neologismos e as diversas considerações apresentadas figuram como um contributo ao trabalho com o desenvolvimento da competência lexical. Como o discurso publicitário é intencionalmente marcado pelo objetivo de influenciar o destinatário a consumir produtos ou serviços, o êxito só é alcançado quando efetivamente ocorre a adesão do consumidor 
ao projeto publicitário. Esse fato corrobora o reconhecimento de que o desenvolvimento da competência lexical é condição indispensável para a compreensão de mensagens publicitárias orais e escritas, em circulação no meio social.

\title{
ADVERTISING SPEECH AND NEW WORDS CREATION: THE DEVELOPMENT OF LEXICAL COMPETENCE
}

\begin{abstract}
This article, in a pedagogical perspective, deals with the development of lexical competence from the analysis of advertising texts and shows the renewal of the lexicon of Brazilian Portuguese by the most common processes of neology. The objective is to emphasize the importance of advertising discourse in the school context, exploring, above all, the aspects of discursive creativity and semantic-lexical innovation. In the context of lexical competence, the article discusses what it means to know a word and, for the conceptuation of neologism, it adopts the lexicographic criterion (ALVES, 1984, 1990; SANDMANN, 1989; CABRÉ, 1993), in which the lexical unit will be neologic if it is not already registered in a language dictionary. In this context, what is intended is to emphasize the work with advertising texts in the Portuguese language classroom, based on a descriptive study of some media neologisms, obtained from advertisements that evidence creativity in Portuguese Brazilian, through the emergence of new words.
\end{abstract}

KEYWORDS: Advertising texts; lexical competence; Neologism.

\section{REFERÊNCIAS}

ALVES, Ieda Maria. Neologismo: criação lexical. São Paulo: Ática, 1990.

. A integração dos neologismos por empréstimo ao léxico português. Alfa. (UNESP), v. 28, suppl, p. 119-126, 1984.

BECHARA, Evanildo. Dicionário da língua portuguesa Evanildo Bechara. Rio de Janeiro: Nova Fronteira, 2011.

Problématique d'une méthodologie d'identification des néologismes en terminologie. In: ADDA, Rosine (Ed.). Néologie et lexicologie: Hommage à Louis Guilbert. Paris: Larousse, 1979, p. 36-46.

BORBA, Francisco da Silva. (Org.) Dicionário Unesp do português contemporâneo. Curitiba: Piá, 2011.

CABRÉ, Maria Teresa. La terminologia. Teoria, metodologia, aplicaciones. Barcelona: Antártida/Empúries, 1993. 
CUNHA, Aline Luiza da. Expressões idiomáticas: da linguagem publicitária para a sala de aula. (Dissertação de Mestrado). Belo Horizonte: Faculdade de Letras, UFMG, 2012.

CRUZ, Ana Flávia Torquetti Domingues. Léxico e livro didático: estratégias para o desenvolvimento da leitura. (Dissertação de Mestrado). Belo Horizonte: Faculdade de Letras, UFMG, 2015.

FERRAZ, Aderlande Pereira. "Publicidade: a linguagem da inovação lexical". In: ALVES, I. M. (Org.) Neologia e neologismos em diferentes perspectivas. São Paulo: Paulistana, 2010, p. 251-275.

Os neologismos no desenvolvimento da competência lexical. In: Língua portuguesa, educação \&o mudança. HENRIQUES, C. C.; SIMÕES, D. (Orgs.). Rio de Janeiro: Europa, 2008, p. 146-162.

GEIGER, Paulo. (Org.) Novíssimo Aulete Dicionário Contemporâneo da Lingua Portuguesa. Rio de Janeiro: Lexikon, 2011.

GONÇALVES, Elizabeth Moraes. Propaganda e linguagem: análise e evolução. São Bernardo do Campo: Universidade Metodista, 2006.

GONÇALVES, Carlos Alexandre. Atuais tendências em formações de palavras. São Paulo: Contexto, 2016.

GUILBERT, Louis. La créativité lexicale. Paris: Larousse, 1975.

IINSTITUTO ANTÔNIO HUAISS. Dicionário Honaisss Conciso. São Paulo: Moderna, 2011.

RICHARDS, Jack. The context f language teaching. Cambridge: Cambridge University Press, 1985.

SANDMANN, Antônio José. Formação de palavras no português brasileiro contemporâneo. Curitiba: Scientia et Labor- Ícone, 1989.

- Morfologia lexical. São Paulo: Contexto, 1992.

SAUSSURE, Ferdinand de. Cours de linguistique générale. Paris: Payot, 1972 [1916].

Recebido em: 09/09/2019.

Aprovado em: 30/10/2019. 